\title{
TAGUNGSBERICHTE
}

\section{Mobilities: Past, Present, and Future}

\author{
Report from the Conference "Spinoffs of \\ Mobility: Technology, Risk \& Innovation" \\ Philadelphia, PA, USA, September 18-21, 2014
}

\section{by Kathleen Oswald, Villanova University, PA, Silke Zimmer-Merkle, and Markus Edelmann, both ITAS}

Transportation history and mobility studies often examine the same objects. The ubiquity of traffic, mobility and transport in our environment makes it an indispensable topic for academic history. Mobility studies in turn often take a retrospective approach, drawing conclusions from the past to understand present and future mobilities. This interdisciplinary approach to mobilities research is the field the International Association for the History of Transport, Traffic and Mobility (T2M) is committed to. It held its 12th Annual Conference this year at Drexel University in Philadelphia. Drexel's Center for Mobilities Research and Policy is a leading institution in mobility studies in the US with an international reach. This year's conference theme was "Spinoffs of Mobility: Technology, Risk \& Innovation" and drew scholars from a variety of disciplines and continents to address historical, contemporary, and emerging T2M issues on air, land, sea, and outer space.

While not exhaustive, this report covers some of the most relevant topics treated at the conference: speed, risk \& safety, accidents \& catastrophes, forgotten alternatives, transport planning, infrastructure and smart mobility. Furthermore, we are presenting inter alia some looming TA-relevant issues, embedding them into their historical context: alternatives, reliability, and intended or unintended effects on complex socio-technical systems. The presentations reviewed here encompass different eras, places and modes, but always the same main topic: transport and mobility.

\section{Speed}

The historical relativism of high speed on passenger railways from 1830 to the present was discussed by Jim Cohen. He asked when and in what context high speed trains were developed. Closely associated with this is the question what actually should be called "high speed"? He showed that high speed, time and spatial distance are socially and historically relative constructs, dividing the development of high-speed trains into four periods: The very first trains (that were $\mathrm{x}$-times faster than what had been known up to that time) brought a new sense of speed in the 1830s and 40s; a second acceleration phase began with the advent of steam trains around 1900-1910; followed by the introduction of streamliners in the 1930s and 40s; and finally the (electric) Japanese Bullet train in the 1960s and 70s representing the final peak of high-speed trains. He concluded by arguing that the denotation "high speed" ensured for some time that these trains could operate profitably. Another panel drew on that very high speed paradigm and showed what "imaginaries" are connected with it and to what extent imagination and vision might influence technological developments.

Peter Lyth took up the high-speed paradigm in his presentation by examining another artefact: His paper "Afterburner glory: Concorde and rise and fall of supersonic travel" focused on the shift in the "mobility paradigm" by Hannam et al. (2006) away from high speed transportation to digital mobility via wide diffusion of high-speed internet and the like.

\section{Risk \& Safety}

Risk - frequently discussed at the conference took on a variety of meanings in various presentations. A panel comprised of researchers from the Smithsonian National Air and Space Museum looked specifically at risk in the air in the US. Two panels took 9/11 as their focus. Dominick Pisano's paper stressed the importance of access to primary documents that would help researchers provide a factual rather than an experiential (public memory) account of events. F. Robert van der Linden gave a historical look at air crime, beginning with the early use of explosives and hijack- 
ings to raise political awareness. He highlighted that while measures such as X-ray scanning and the Hague Hijacking Convention in the 1970s cut down on hijackings, it caused a return to in-flight bombing. A third presentation looked at early smuggling by air, arguing that while organized crime used planes to smuggle alcohol during Prohibition, smuggling was actually evident soon after the plane itself and was used to avoid tariffs.

Valerie Neal of the Smithsonian National Air and Space Museum presented a paper titled "Space Travel: A Rhetoric of Routine, Research, Risk and Renewal" that focused on NASA's use of visual and verbal rhetoric in the 1970s and 80s. Her analysis revealed the extent to which NASA leveraged themes of utilization and routine, which held until the 1986 Challenger accident after which rhetoric shifted to one of "risk" and the shuttle was reframed as a space lab. With developments in space craft increasingly coming from private industry, Neal explains, NASA is today presenting itself as an engine of innovation with their newest campaigns, such as Next Giant Leap.

An entire panel was dedicated to the topic of Automobilism \& Risk Society. Fabrice Hamelin gave insight into research policies in his presentation on "Science and Road Safety Policies: a comparison between France and England". From another point of view, Fabian Kröger approached the risks of transport, especially automobilism, in his paper on "Car accidents and crashes in French and US-film history." The panel was completed by Pierre Lannoy's presentation on "Securing transport/animal encounters, or how to distribute responsibilities for disturbed traffics", who again threw the focus on risk from a very different angle. Adjacent to that, Silke Zimmer discussed the evolution of driver assistance systems over the last fifty years.

\section{Accidents, Catastrophes and the Uncanny}

Beginning with natural catastrophes and their influence on transportation, Mark Barnes' paper "Public Transit System Legacies and Uncertain Mobilities" discussed the lasting impact of historical infrastructural and institutional structures in the way transportation authorities in the region handle extreme weather events and adapt to cli- mate change. A very similar topic was brought up by Rae Zimmerman in her keynote on "Adapting Transportation to Global Risk Challenges" that widely focused on the consequences of climate change and the resulting "extreme weather events" that are becoming increasingly important to transportation planners in the US. By contrast, the resilience of transportation systems has been on the agenda of European transportation planners for a long time. The effects of natural catastrophes were highlighted by Alejandro Crispiani and Tomás Errázuriz, who illuminated in their paper "Deconstructing mobility: uncovering the paradigm after the crisis" what happens after a severe earthquake, when houses are destroyed, transport infrastructure is demolished, and people assemble in the streets, having lost their homes, trying to cope with the situation.

Norman Kellerman focused on the railway accident at Santiago de Compostela. For his analysis, he has taken into account the theoretical concepts of both the high reliability and the inevitable accidents theories. He concluded that a multitude of unfortunate factors are responsible for the disaster, in contrast to earlier single causality estimation. He argued that a central lesson could be to achieve further improvements in the system in order to enhance its redundancy performance. Nevertheless, every ingenious technical answer has its limits and is not able to guarantee an entirely safe transport system. Norman Kellerman reminded us that there can be no technology without any uncertainties, despite all technological desires and expectations.

\section{Mobilities and Forgotten Alternatives}

Massimo Moraglio's “Elapsed Mobilities: Technology salvation, debris and Benjamin's Angelus Novus" critically scrutinized the mobility concepts of the 21 st century. He connected the thesis of David Edgerton - that "calling for innovation is, paradoxically, a common way of avoiding change when change is not wanted" (Edgerton 2006, p. 210) - with the Angelus Novus concept by Walter Benjamin. He compared the way today's obsessive technological fix approach is working with how the Angelus Novus is acting. In other words, new and improved high-tech- 
nology solutions (as electric cars or driverless vehicles) are seen as the answer to the mobility failures of the past. Moraglio argued to not forget in the debate apparently "old" or "peripheral" mobility modes (as e.g. cycling, walking or car sharing). He stated that they have a noteworthy history - and proposed a look into it.

In his contribution "Spinning off the Path: The Failed Dream of Bicycle Paths in the 1890s and the Unintended Spinoff of a Combined Transportation System", James Longhurst demonstrated how interesting historical artifacts could make for a controversial debate today. $\mathrm{He}$ describes the development process of the cycle path movement, beginning in the United States in the $1890 \mathrm{~s}$. The promotion of separate cycle paths failed due to the political dispute about taxation for public infrastructure. Longhurst showed that today's combined American road system was not inevitable - there were plenty of alternatives in the past. His forgotten cycling history issue is absolutely up-to-date in our time of an unbowed bike riding trend.

The cycling debate was also addressed by Katalin Tóth in her presentation examining the uncertainties and challenges accompanying the introduction of new mobilities by the example of bike sharing in Budapest. She highlighted the impact of socio-cultural contexts and policy stakeholders, explaining that complex public reactions weakened support for the initiative and suggested a more demand- and user-oriented procedure by policy makers.

\section{Transport Planning, Infrastructure and Smart Mobility}

One panel brought transport planning into focus. Richard Harrison examined urban transportation planning in post-war Britain, explaining that the future of Britain was seen as being tied to road reorganization largely decided at transportation engineering conferences. The last paper, given by Cheryl Deutsch, looked at early metropolitan transport planning driven by engineering and sociology. Some examples of early research included origin and destination surveys and transportation studies to launch urban highways.
Another presentation that examined the past to understand present (and future) contexts was presented by Sharon Babian of the Canada Science and Technology Museum. The paper, titled "Navigation Made Easy? The Promise and Perils of Electronic Navigation at Sea", focused on mariners' use of Electronic Chart Display \& Information Systems (ECDIS). After reviewing the early use of radar and the development of automatic radar plotting aids (ARPA), she discussed potential concerns with ECDIS, including deliberate jamming and disruptive anomalies. She concluded by indicating that there is increasing interest in eliminating crew through autonomous piloting technologies. Electronic systems - more specifically communication systems - were taken up on a separate panel by Kathleen Oswald who gave "A Brief History of Smart Transportation Infrastructure" that was followed by Markus Edelmann's and Silke Zimmer's paper on "Autonomous Driving from the Perspective of History and Technology Assessment". Together, the presentations opened up a vivid discussion on smart mobility.

On another panel, Lyubomir Pozharliev's paper "Collectivity vs. Connectivity: The techno-historical example of motorway peripherization in former Yugoslavia" illustrated intended and unintended effects of the development of a motorway infrastructure by Tito's regime during the Cold War. Pozharliev's main argument is that, in spite of the clear ideological objective to build a national identity by constructing motorways, it was not possible to envision what kinds of development a motorized individual transport system would trigger. He argues that it had the contrary effect in a process that reinforced the formerly strong urban economic areas and abandoned the few industrialized ones. Thus, it contributed to secessionist movements and tensions in the regions of Yugoslavia. Pozharliev demonstrated the undesirable consequences of an ideological overflow in a planning concept, in contrast to more open and integrated transport planning approaches. Interesting is the example for today's future mobility visions as it illustrates the well-existing tension between the appeal of possibilities and the variability of effects. 


\section{Conclusion}

The interdisciplinary nature of the conference as well as the wide range of topics and approaches at times led to a feeling of being at many conferences at once. At the same time, conference attendees from around the world and in many disciplines took the opportunity to hear research outside of their usual areas of focus and emplace their work in a wider context that includes the development of rail networks before World War I, routine space flight in the 1980s, and the end of streetcar service in Detroit: all important moments in traffic, transport, and mobility. Working at the horizon of culturally impactful new mobilities, it is useful to reflect on a time when old technologies were new: how they were implemented, what they meant during historical times of technological change.

Also within the scope of technology assessment the conference had to offer interdisciplinary and global perspectives of multiple forms of mobility through time. These quite often were fascinating, even if the many goals of the individual papers and presentations were not always congruent. While the mission of interdisciplinarity was mainly fulfilled by juxtaposing papers from different disciplines on a panel rather than in the active connection of those approaches, T2M is working to strengthen these connections. At next year's meeting from September 14 to 17, 2015, T2M intends to counteract this trend with a deeper focus on methods as they join with the sociologist Cosmobilities Network in Santa Maria C.V. (Caserta), Italy, on the topic of "The Future of Mobilities: Flows, Transport and Communication".

Overall, this was a refreshing conference worth attending, particularly if one is interested in situating or understanding one's research more broadly in the long and diverse histories of traffic, transport and mobility that the T2M conference has to offer.

\section{References}

Hannam, K.; Sheller, M.; Urry, J., 2006: Editorial: Mobilities, Immobilities and Moorings. In: Mobilities 1/1 (2006), pp. 1-22

Edgerton, D., 2006: The Shock of the Old. Technology and Global History since 1900. London

\section{$\ll 》$}

\section{Der ländliche Raum als Schauplatz der Energiewende}

\author{
Multidisziplinäre Perspektiven auf \\ einen komplexen soziotechnischen \\ Transformationsprozess
}

Bericht zur Tagung „Energiewende im ländlichen Raum - Ein Bürgerprojekt auf dem Prüfstand" an der Evangelischen Akademie Tutzing

Tutzing, 25.-26. Juni 2014

\section{von Florian Braun, Universität Kiel, und Martin Knapp, ITAS}

Der ländliche Raum als zentraler Ort für die Umsetzung der Energiewende stand im Fokus dieser Konferenz. Durchgeführt wurde sie in Kooperation mit dem Institut Technik-Theologie-Naturwissenschaften (TTN) an der LMU München und dem Technologie- und Förderzentrum (TFZ) am Kompetenzzentrum für Nachwachsende Rohstoffe Straubing. Veränderungen, Konflikte und Herausforderungen wurden einleitend von Akademiechef Frank Kittelberger, Stephan Schleissing (TTN) und Bernhard Widmann (TFZ) aufgegriffen.

\section{Umsetzung der Energiewende im ländlichen Raum}

Trotz der aktuellen Kontroverse rund um die Novellierung des Erneuerbare-Energien-Gesetzes (EEG) stimmen weite Teile der Gesellschaft v. a. aufgrund der Aussicht auf eine klimaneutrale Energieversorgung den allgemeinen Zielen der Energiewende weiterhin zu. Um das klimapolitische Ziel der Treibhausgasminimierung zu erreichen, müssen neben dem Stromsegment auch Wärme und Mobilität betrachtet werden. So stellt der v. a. in Süddeutschland zu weiten Teilen aus Biomasse gedeckte Bedarf an erneuerbarer Wärme eine wesentliche Anforderung an den ländlichen Raum hinsichtlich Produktion und Flächenbereitstellung dar.

Nichtsdestotrotz bahnen sich Konflikte an, je näher die Umsetzung konkreter Projekte an das Lebensumfeld der Bevölkerung rückt, das Land- 